\title{
Depletion of $\beta$-sitosterol and enrichment of quercetin and rutin in Cissus quadrangularis Linn fraction enhanced osteogenic but reduced osteoclastogenic marker expression
}

Jetsada Ruangsuriya ${ }^{1,2}$, Suporn Charumanee ${ }^{3}$, Supat Jiranusornkul ${ }^{3}$, Panee Sirisa-ard ${ }^{3}$, Busaban Sirithunyalug ${ }^{3}$, Jakkapan Sirithunyalug ${ }^{3}$, Thanawat Pattananandecha ${ }^{2,3}$ and Chalermpong Saenjum ${ }^{2,3^{*}}$

\begin{abstract}
Background: Cissus quadrangularis Linn. (CQ) has been used in Indian and Thai traditional medicine for healing bone fractures because of numerous active ingredients in CQ. It is still unclear which compounds are the active ingredients for bone formation.

Methods: The molecular docking technique, the ethanolic extraction along with hexane fractionation, and an in vitro experiment with a human osteoblast cell line (MG-63) were used to narrow down the active compounds, to prepare the CQ extract, and to test biological activities, respectively.

Results: The molecular docking technique revealed that quercetin and $\beta$-sitosterol had highest and lowest potential to bind to estrogen receptors, respectively. Compared to the crude ethanol extract (P1), the ethanolic fraction (P2) was enriched with rutin and quercetin at $65.36 \pm 0.75$ and $1.06 \pm 0.12 \mathrm{mg} / \mathrm{g}$, respectively. Alkaline phosphatase (ALP) activity was significantly enhanced in osteoblasts exposed to the P2 in both tested concentrations. The amount of hydroxyproline was slightly increased in the P1 treatment, while osteocalcin was inhibited. Moreover, the P2 significantly activated osteoprotegerin (OPG) and inhibited receptor activator of nuclear factor $\mathrm{K}$ ligand (RANKL) expression.
\end{abstract}

Conclusions: Taken together, the enriched rutin and quercetin fraction of CQ triggered the molecules involved in bone formation and the molecules inhibiting bone resorption.

Keywords: Cissus quadrangularis Linn, Osteoporosis, Human osteoblast cell line, Ethanolic fractionation

\footnotetext{
* Correspondence: chalermpong.saenjum@gmail.com

${ }^{2}$ Cluster of Excellence on Biodiversity based Economic and Society

(B.BES-CMU), Chiang Mai University, Chiang Mai, Thailand

${ }^{3}$ Department of Pharmaceutical Sciences, Faculty of Pharmacy, Chiang Mai

University, Chiang Mai 50200, Thailand

Full list of author information is available at the end of the article
}

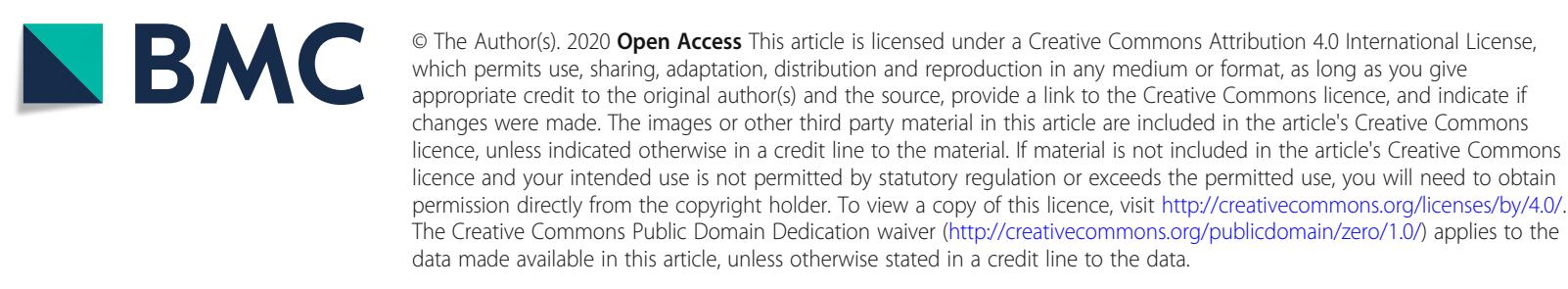




\section{Background}

Osteoporosis is an age-related disease, which is attributed to a relatively low bone mineral density (BMD) when compared with normal individuals. This phenomenon is due to the imbalance of the bone remodeling process, in which the rate of bone resorption is much higher than that of bone formation, leading to bone loss and risk of bone fractures [1]. The primary cause of osteoporosis is the deficiency of sex steroid hormones, estrogen and/or testosterone. Even though the incidences of osteoporosis are dominantly found in women, men could be suffered from osteoporosis in similar fashions [2]. Currently, standard treatments of osteoporosis pose various side effects and shortcomings [3]. Even though novel drugs for osteoporosis treatments that act on different targets of the disease mechanisms have been developed [4], searching for medicinal plants to rectifying the imbalance of bone metabolism is also a great potential alternative. One of the potential plant candidates is Cissus quadrangularis Linn (CQ), which has been claimed to promote bone formation in traditional Indian medicine.

$\mathrm{CQ}$, is commonly found in tropical countries and has been reported as a traditional medicinal plant for the treatment of many diseases. The stems of CQ have been reported to contain various biological activities - e.g. antioxidative as well as antimicrobial activities [5], antinociceptive potential [6], abilities to protect and heal peptic ulcers [7], induction of weight loss in obese subjects [8], properties such as an anticonvulsant, an analgesic, a smooth muscle relaxant [9], activities against hemorrhoids [10] as well as atherosclerosis [11], and acceleration of bone fracture healing [12, 13]. However, the effects of CQ on bone are more prominent than others. Ethanolic extracts of CQ supported bone formation in fetal rats when administered to the pregnant rats [14]. In addition, the ethanol extract of the CQ enhanced alkaline phosphatase (ALP) activity, a classical marker for bone formation, in murine osteoblasts occurs via the MAPK (mitogen-activated protein kinase) signaling pathway [15]. By using an osteoblastic cell line (SaOS-2) as a model, the CQ extract showed its ability to promote cellular proliferation and matrix calcification by promoting the expression of IGF-I, II and IGFBP-3 [16, 17]. Apart from the ethanolic part, petroleum ether extract of the CQ exhibited similar effect on promoting osteoblastic differentiation of rat bone marrow mesenchymal stem cells [18]. Furthermore, the studies using ovarectomised (OVX) animal models, a standard model for osteoporosis, strongly indicated the effect of CQ extract on amelioration of osteoporotic conditions in OVX mice [19] and rats [20-23], indicated by the increase in bone mass and bone mineral density. The evidence here strongly suggested that there might be certain active chemical ingredients in CQ extracts.
The varieties of chemical components in CQ have been documented. Stems of CQ contain a relatively higher amount of alkaloids and phenols than those of its roots and its leaves [24]. Calcium oxalate, cardiac glycosides, flavonoids, kaempferol, quercetin, stilbene derivatives, tannins, triterpenes ( $\alpha-, \beta$-amyrins) were also reported $[25,26]$. It has further been reviewed that ascorbic acid, triterpene, $\beta$-sitosterol, ketosteroids, two asymmetrical tetracyclic triterpenoids, and calcium were the major compounds found in CQ [27]. However, it has not been ascertained which components are the actual active compounds due to the divergence of documented evidence. In this study, it was concluded from previous literature $[14-17,20,22]$ that ethanolic extract of CQ might be of benefit to bone metabolism. Hence, the objective of this study was to investigate the responses of osteoblastic cell line (MG-63 cells) upon the treatment of CQ extract derived from $80 \%$ ethanol extraction, and partitioned by hexane, with the focus on active ingredients from molecular docking technique guidance.

\section{Methods}

\section{Chemicals and reagents}

Quercetin dihydrate (HWI ANALYTIK GmBH, Germany), $\beta$-sitosterol (Sigma, USA), Human sRANKLigand (EDK) (PREPROTECH), Human Osteocalcin Instant ELISA (eBioscience), Human Osteoprotegerin Instant ELISA (eBioscience), Quant-iT PicoGreen dsDNA Assay Kit (Invitrogen, USA).

\section{Molecular docking studies}

As there are varieties of biological active compounds in CQ extract, molecular docking could narrow down the group of the compound we should focus on. Activations of estrogen receptors (ER) through those active compounds potentially activate the cellular activity and support bone health. Initially, 2D and 3D structures of two biologically active compounds in CQ extract, quercetin and $\beta$-sitosterol (Fig. 1), two known natural positive controls, genistein and diadzein, and estradiol (Fig. 1) as a physiological positive control were drawn using ChemBioOffice 2012. Then, all compounds were docked and analyzed using CDOCKER in Discover Studio version 2.5. The more the negative energy gains, the higher the affinity binds to ER.

\section{Preparation of CQ extract}

CQ was collected from Lampang Herb Conservation, Lampang province, Thailand on December, 2013. A voucher specimen was prepared and preserved at the Faculty of Pharmacy, Chiang Mai University. An aerial part of CQ was cleaned, dried and ground into coarse powder. The powder was extracted with $80 \%$ ethanol at $80^{\circ} \mathrm{C}$. An obtained solution was separated into two equal 
(A)<smiles>O=c1c(O)c(-c2ccc(O)c(O)c2)oc2cc(O)cc(O)c12</smiles>

(C)<smiles>O=c1c(-c2ccc(O)cc2)coc2cc(O)cc(O)c12</smiles>

(E)

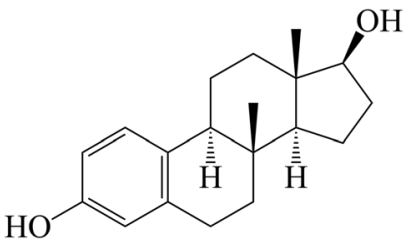

(B)<smiles>CC(C)[C@@H](C)CC[C@H](C)[C@H]1CC[C@H]2[C@@H]3CC=C4CC(O)CC[C@]4(C)[C@H]3CC[C@@]21C</smiles>

(D)<smiles>O=c1c(-c2ccc(O)cc2)coc2cc(O)ccc12</smiles>

Fig. 1 Chemical structures of candidate compounds used in the molecular docking study a quercetin, b $\beta$-sitosterol, c genistein, d diadzein, and e estradiol

parts for sample preparation. The first part of the solution was filtered and removed from the solvent under reduced pressure. The ultimate yields of the ethanolic extract (crude extract), which was designated as P1, were also recorded. The second part of the solution was partitioned with hexane to eliminate non-polar compounds. Only the ethanolic fraction was collected and removed from the solvent under reduced pressure. Finally, the ultimate yield of the ethanolic fraction, designated as P2, was also recorded.

The extracts were dissolved in DMSO (Dimethyl sulfoxide) and supplemented into cell culture medium containing the extracts of $\mathrm{P} 1$ or $\mathrm{P} 2$ at 50 and $100 \mathrm{ppm}$, with the final concentration of the DMSO less than $0.05 \% v / v$. This set of mediums was called the "conditioned medium".

\section{Determination of $\beta$-sitosterol, quercetin and rutin in the CQ extracts by reversed-phase HPLC}

The contents of $\beta$-sitosterol, quercetin and rutin in the CQ extracts were determined by using reversed-phase HPLC (RP-HPLC) from Shimadzu system (Japan), including LC-10AV VP pumps and SPD-10AV VP with UV detector. The column for the separation was $250 \times$ $4.6 \mathrm{~mm}$ in diameter (SymmetryShield RP18 C18 (Water Co, Ltd.)). Mobile phases used for determination of $\beta$ sitosterol [28], quercetin [29], and rutin [30] were acetonitrile:methanol (85:15), $5 \mathrm{mM} \mathrm{KHPO}_{4}$ :acetonitrile: methanol (49:40:11), and de-ionized (DI) $\mathrm{H}_{2} \mathrm{O}$ :methanol: triethylamine (60:40:0.1), respectively. The flow rates and detection wavelengths for $\beta$-sitosterol, quercetin, and rutin were $1.0,0.7,0.5 \mathrm{~mL} / \mathrm{min}$ and at the wavelength of 202, 350, $256 \mathrm{~nm}$, respectively. Both of the CQ extracts, P1 and P2, were subjected to the RP-HPLC in parallel with the correlated known concentration standards, $\beta$-sitosterol (Sigma, USA), quercetin dihydrate (GmBH, Germany) and rutin (Sigma, USA). The concentrations of the three compounds were calculated from the peak areas using the calibration curves. The results were performed in triplicate.

\section{Culture of MG-63 cells and biochemical tests Cell culture and treatments}

MG-63 cells were purchased from American Type Culture Collection (ATCC, CRL-1427). The cells were cultured in Dulbecco's modified eagle medium (DMEM) and supplemented with $10 \%$ fetal bovine serum (FBS), 1\% Penicillin/ Streptomycin and $1 \%$ non-essential amino acids. Upon confluence, the cells were trypsinised and plated at $1.0 \times$ $10^{4}$ cells $/ \mathrm{cm}^{2}$ into each well of 24 -well plates or 96 -well plates, and were performed in triplicate, per treatment condition. After $24 \mathrm{~h}$ of plating cells, the culture medium was replaced with the conditioned media containing different concentrations of P1 or P2. The plates were incubated at $37^{\circ} \mathrm{C}$ in a humidified condition containing $5 \%$ $\mathrm{CO}_{2}$ for 4 and $7 \mathrm{~d}$, with medium change at a $4 \mathrm{~d}$ interval.

Culture medium supernatants were collected, and the cells were lysed to yield cell lysates using CelLytic ${ }^{\mathrm{Tm}} \mathrm{M}$ Cell Lysis Buffer (Sigma, C2978) and stored at $-80^{\circ} \mathrm{C}$ for further analyses. 


\section{Cytotoxicity test by WST-1 assay}

MG-63 cells were plated into each well of a 96-well plate and treated with the culture media containing either P1 or P2 at different concentrations from 25 to $200 \mathrm{ppm}$ for $4 \mathrm{~d}$. Cell proliferation reagent WST-1 (Roche, Switzerland) was added into the treated cells and the plate was then incubated at $37^{\circ} \mathrm{C}$ for $45 \mathrm{~min}$. The absorbance of each well of the plate was read at $445 \mathrm{~nm}$ using a multimode detector (Beckman Coulter, USA). Cell viability was then calculated relative to the untreated control.

\section{DNA and protein measurement}

The amount of DNA was quantified by Quant-iT PicoGreen Assay (Invitrogen, P11496), according to manufacturer's protocols. Briefly, $10 \mu \mathrm{L}$ of the cell lysates was mixed with a working concentration of the dye, and the fluorescent data were collected at the wavelength of excitation $(480 \mathrm{~nm})$ and emission $(530 \mathrm{~nm})$ using the multimode detector. The $\lambda \mathrm{DNA}$ at different concentrations was used to establish a standard curve.

The protein produced by MG-63 cells was analyzed using house-prepared Bradford reagent by adding $10 \mu \mathrm{L}$ of the cell lysates into $90 \mu \mathrm{L}$ of working Bradford solution. The absorbance data at $595 \mathrm{~nm}$ of the mixture were collected with the multimode detector. The bovine serum albumin (BSA) at different concentrations was used to establish a standard curve.

\section{Quantification of hydroxyproline}

The hydroxyproline was measured in the lysate by RPHPLC according to the methods described elsewhere [31] with slight modifications. Briefly, the lysates were subjected to acid hydrolysis using $6 \mathrm{M} \mathrm{HCl}$ and measured, to obtain hydroxyproline, by RP-HPLC. The column used in this analysis was Kinetex C18 column, $250 \times 4.6 \mathrm{~mm}$ in diameter (Phenomenex Co., Ltd.). The mobile phase consisted of $100 \mathrm{mM}$ sodium acetate buffer and acetronitrile (93:7) with the flow rate of $0.3 \mathrm{~mL} / \mathrm{min}$, and the wavelength for detection was at $495 \mathrm{~nm}$. Different concentrations of the standard hydroxyproline were used to set a standard curve, and the amounts of hydroxyproline in all samples were calculated accordingly.
Determination of alkaline phosphatase (ALP) activity

ALP activity was determined by the rate of $p$-nitrophenol phosphate (pNPP) conversion to $p$-nitrophenol (pNP). Briefly, $10 \mu \mathrm{L}$ of the cell lysates was added into $90 \mu \mathrm{L}$ of $1 \mathrm{mM}$ pNPP in the diethanolamine buffer, $\mathrm{pH}$ 9.8. The mixture was mixed well and incubated at $37^{\circ} \mathrm{C}$ for $75 \mathrm{~min}$. The reaction was then stopped by adding $25 \mu \mathrm{L}$ of $1 \mathrm{M} \mathrm{NaOH}$ solution into the reaction mixture, and the absorbance was read at $405 \mathrm{~nm}$ using the multimode detector. The standard solution of pNP at different concentrations in the buffer was used to establish a standard curve. The ALP activity was expressed in the normalized values of the total protein.

\section{Detection of osteocalcin (OC), osteoprotegerin (OPG), and receptor activator of nuclear factor kappa ligand (RANKL) expression by ELISA}

Commercially available ELISA kits were used to measure the expression levels of OC, OPG, and RANKL. The kits for determination of OC (BMS2020INST) and OPG (BMS2021INST) were purchased from eBioscience, while that of RANKL (900-K142) was from PreproTech. The procedures to determine the level of expression followed the manufacturer protocols, accordingly.

\section{Statistical analysis}

One way analysis of variance (one way ANOVA), followed by Tukey tests using StatPlus version 5.8.2.0 were employed to differentiate the significant levels among the data sets with $95 \%$ confidence $(p<0.05)$.

\section{Results}

Molecular docking studies

The preliminary computerized analyses by molecular docking techniques suggested that quercetin had highest potential to bind to ER in both forms whereas $\beta$-sitosterol had the lowest capability (Table 1). Quercetin had the lowest potential energy at $-4.85 \mathrm{kcal} / \mathrm{mol}$, the lowest differences of the two terminal hydroxyl groups at $10.8{ }^{\circ} \mathrm{A}$, and the lowest CDOCKER energy at -32.08 and -37.22 $\mathrm{kcal} / \mathrm{mol}$ for $\alpha$-ER and $\beta$-ER, respectively. In contrast, $\beta$ sitosterol had the highest potential energy at $61.91 \mathrm{kcal} /$ mol, had no two terminal hydroxyl groups, and the

Table 1 Molecular docking parameters of the active compound candidates in CQ extract

\begin{tabular}{lllll}
\hline $\begin{array}{l}\text { Candidate } \\
\text { molecules }\end{array}$ & $\begin{array}{l}\text { Potential energy } \\
(\mathrm{kcal} / \mathrm{mol})\end{array}$ & $\begin{array}{l}\text { Distance between } \\
\text { two terminal } \\
\text { hydroxyl groups }\left({ }^{\circ} \mathrm{A}\right)\end{array}$ & \multicolumn{2}{c}{\begin{tabular}{l} 
CDOCKER energy $(\mathrm{kcal} / \mathrm{mol})$ \\
\cline { 3 - 5 } a-ER
\end{tabular}} \\
\hline Estradiol & 24.05 & 10.9 & -11.11 & -6.05 \\
Quercetin & -4.85 & 10.8 & -32.08 & -37.22 \\
$\beta$-sitosterol & 61.97 & $\mathrm{NA}$ & 165.80 & -360.14 \\
Genistein & 6.69 & 12.2 & -32.07 & -35.90 \\
Diadzein & 5.84 & 12.2 & -31.12 & -34.38 \\
\hline
\end{tabular}


highest CDOCKER energy at 165.80 and $260.14 \mathrm{kcal} / \mathrm{mol}$ for $\alpha$-ER and $\beta$-ER, respectively. The binding mode of estradiol, genistein, daidzein, and quercetin with their hydrogen bonding were shown in Fig. 2. According to the molecular docking results indicating the lowest binding energy of quercetin for both $\alpha$-ER and $\beta$-ER, we continued to focus on the presence of quercetin in the CQ extract. In addition, rutin, a glycosylated form of quercetin, was also focused in this study.
Determination of $\beta$-sitosterol, quercetin, and rutin in the CQ extracts by RP-HPLC

The results from RP-HPLC analyses indicated that a hexane partition completely removed $\beta$-sitosterol and enriched quercetin, as well as rutin in the CQ extract (Fig. 3). The crude ethanolic extract (P1) contained $\beta$ sitosterol $2.45 \pm 0.27 \mathrm{mg} / \mathrm{g}$, quercetin $0.97 \pm 0.14 \mathrm{mg} / \mathrm{g}$, and rutin $30.41 \pm 0.24 \mathrm{mg} / \mathrm{g}$. After a hexane partition, the ethanolic fraction (P2) contained an undetectable
(A)

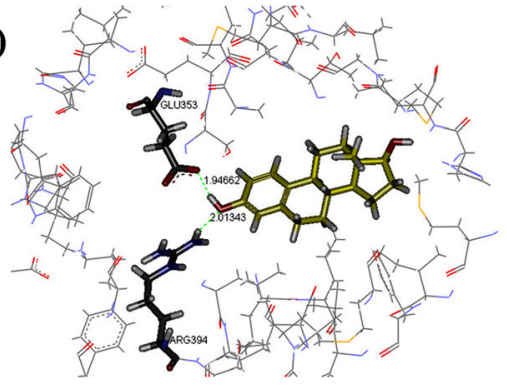

(B)

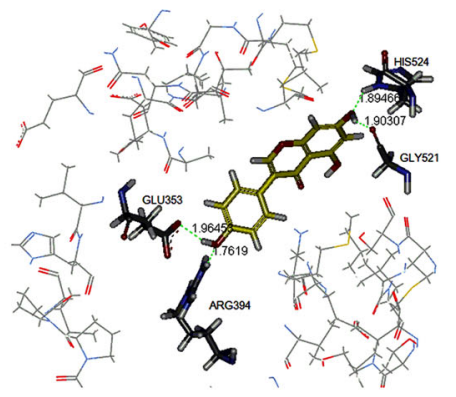

(C)

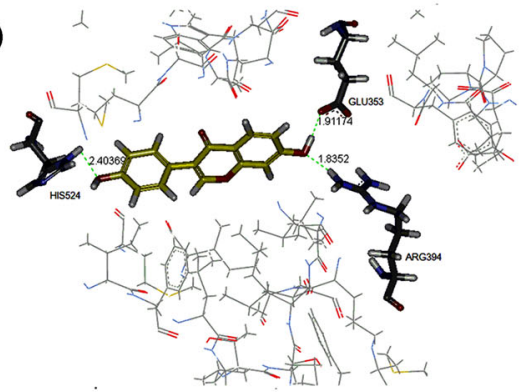

(D)

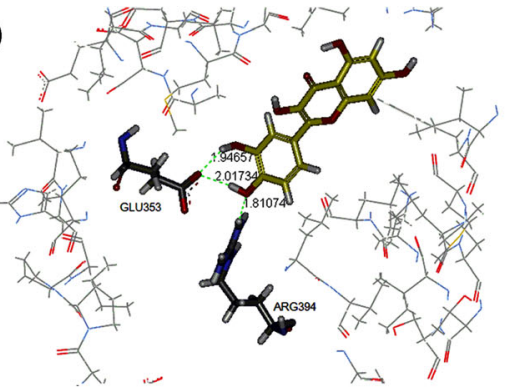

(E)

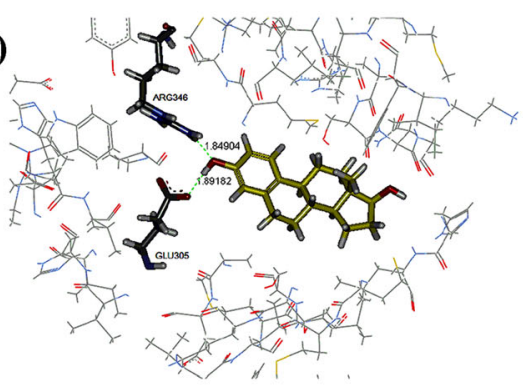

(F)
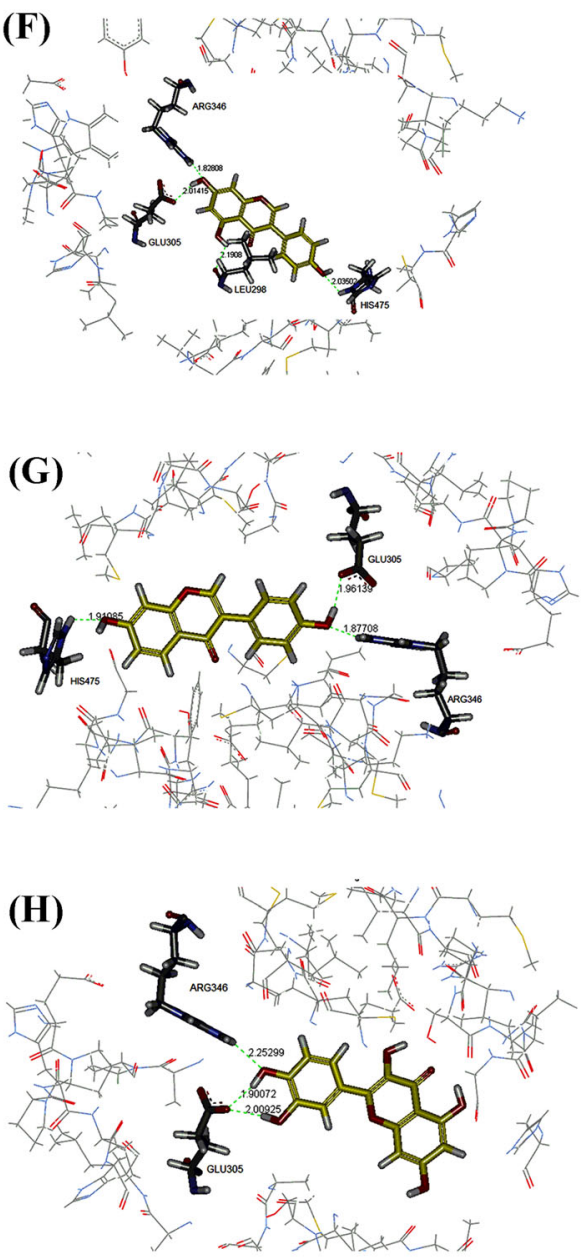

Fig. 2 Predicted binding mode of estrogen and phytoestrogens complexed to a-ER (a: estradiol, b: genistein, c: diadzein, and $\mathbf{d}$ : quercetin) and $\beta$-ER estradiol (e: estradiol, $\mathbf{f}$ : genistein, $\mathbf{g}$ : diadzein, and $\mathbf{h}$ : quercetin) 


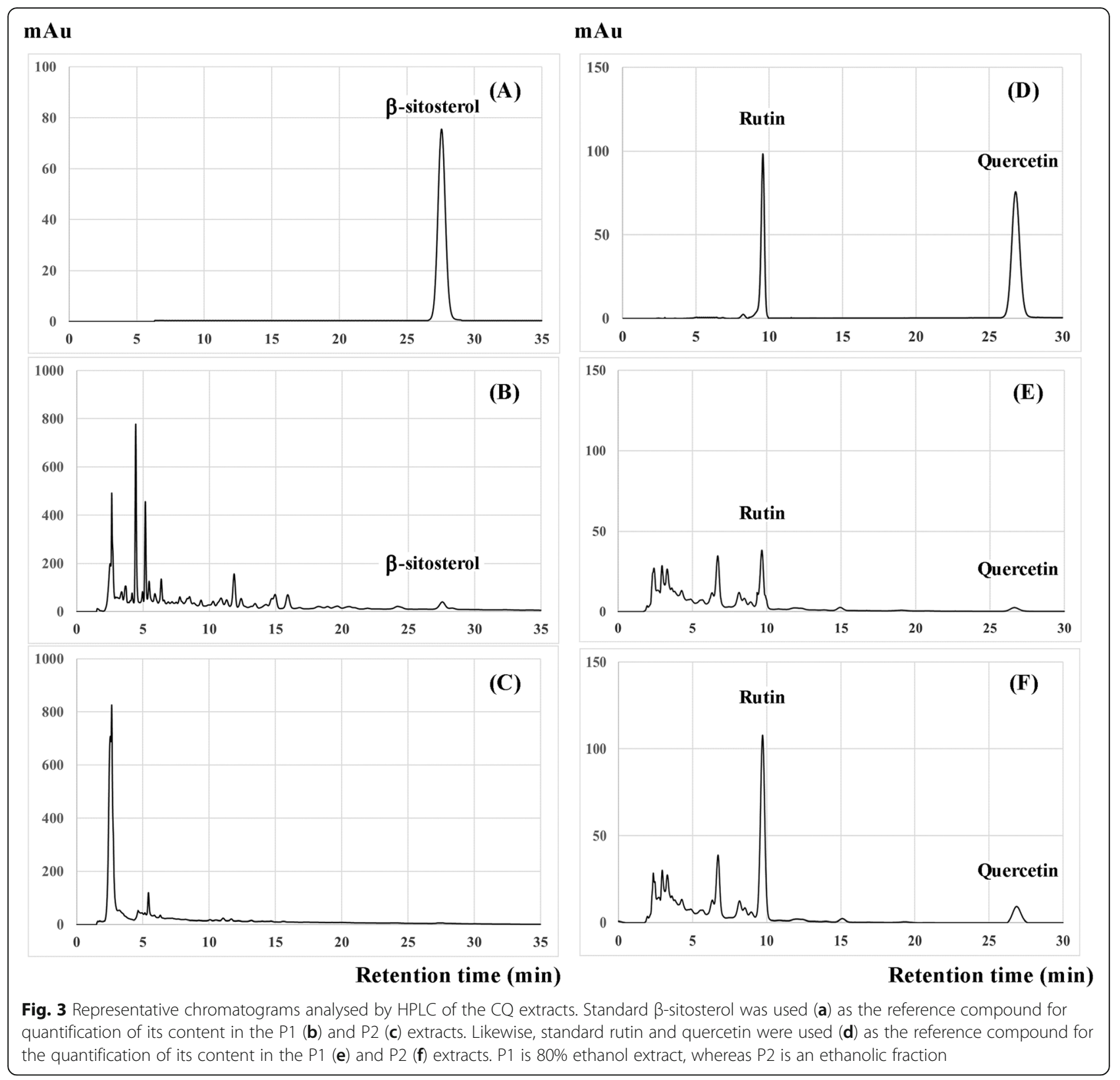

amount of $\beta$-sitosterol, a stable amount of quercetin $1.06 \pm 0.12 \mathrm{mg} / \mathrm{g}$ and an increasing amount of rutin $65.36 \pm 0.75 \mathrm{mg} / \mathrm{g}$.

\section{Cytotoxicity, DNA contents, and protein production of MG-63 exposed to P1 and P2}

P2 significantly increased the amount of DNA in MG-63, but did not affect total protein production and cell viability. The viability of MG-63 cells on the exposure of both $\mathrm{P} 1$ and $\mathrm{P} 2$ at a concentration range of 25-200 ppm remained the same as that of the control (Fig. 4). The amount of the DNA, which indicates the ability of the cells to proliferate, clearly showed that P2 significantly activated cell proliferation at both time points, especially at $100 \mathrm{ppm}$ in its concentration (Fig. 5a). In contrast, P1 had no effect on cell proliferation. However, both P1 and P2 did not alter the ability of the cells to produce total proteins (Fig. 5b).

\section{Expression of markers indicating bone formation}

P2 significantly activated the activity of ALP, which increased the level of collagen, but reduced the expression of OC. It was clearly shown that P2 at both 50 and $100 \mathrm{ppm}$ significantly enhanced ALP activity of MG-63 cells in both time points. In contrast, P1 at both 50 and $100 \mathrm{ppm}$ significantly inhibited the activity of ALP (Fig. 6). 

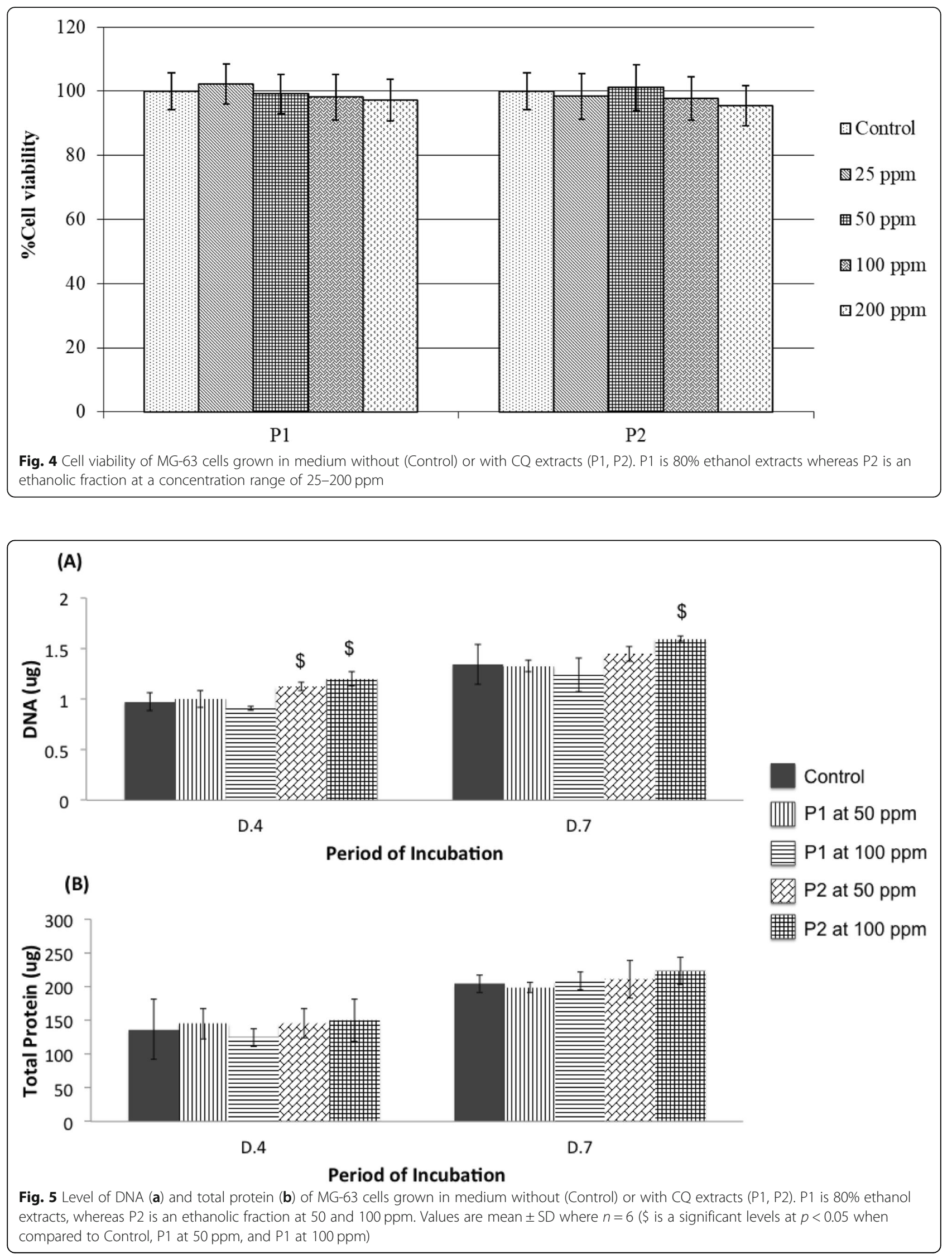


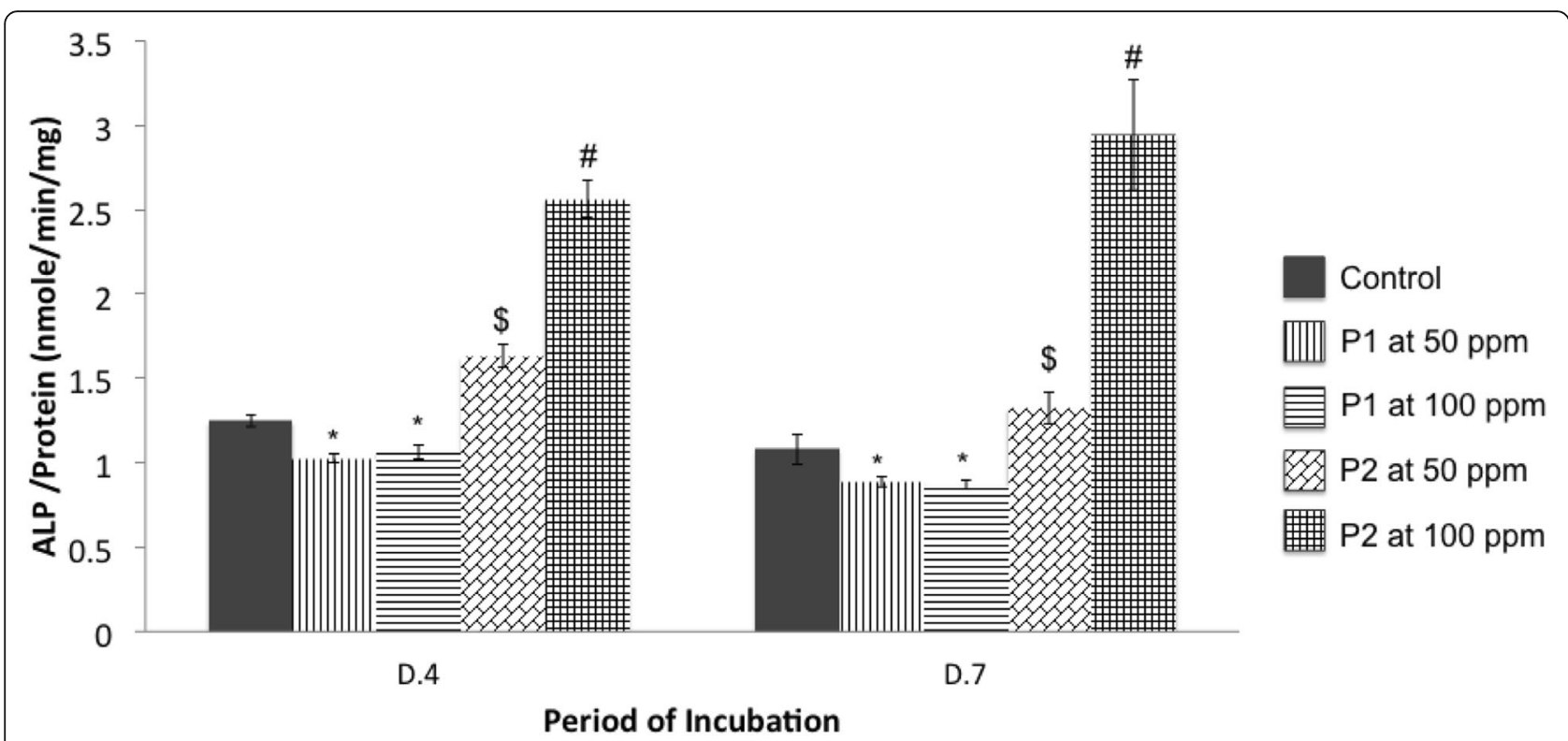

Fig. 6 The activity of alkaline phosphatase (ALP) normalized with total protein from MG-63 cells grown in medium without (Control) or with CQ extracts (P1, P2). P1 is 80\% ethanol extracts whereas P2 is an ethanolic fraction at 50 and $100 \mathrm{ppm}$. Values are mean \pm SD where $n=6$ (\#, \$, and * are a significant difference at $p<0.05$; \# compared to Control, P1 at 50 ppm, P1 at 100 ppm, and P2 at 50 ppm, \$ compared to Control, P1 at 50 ppm, and P1 at 100 ppm, and * compared to Control)

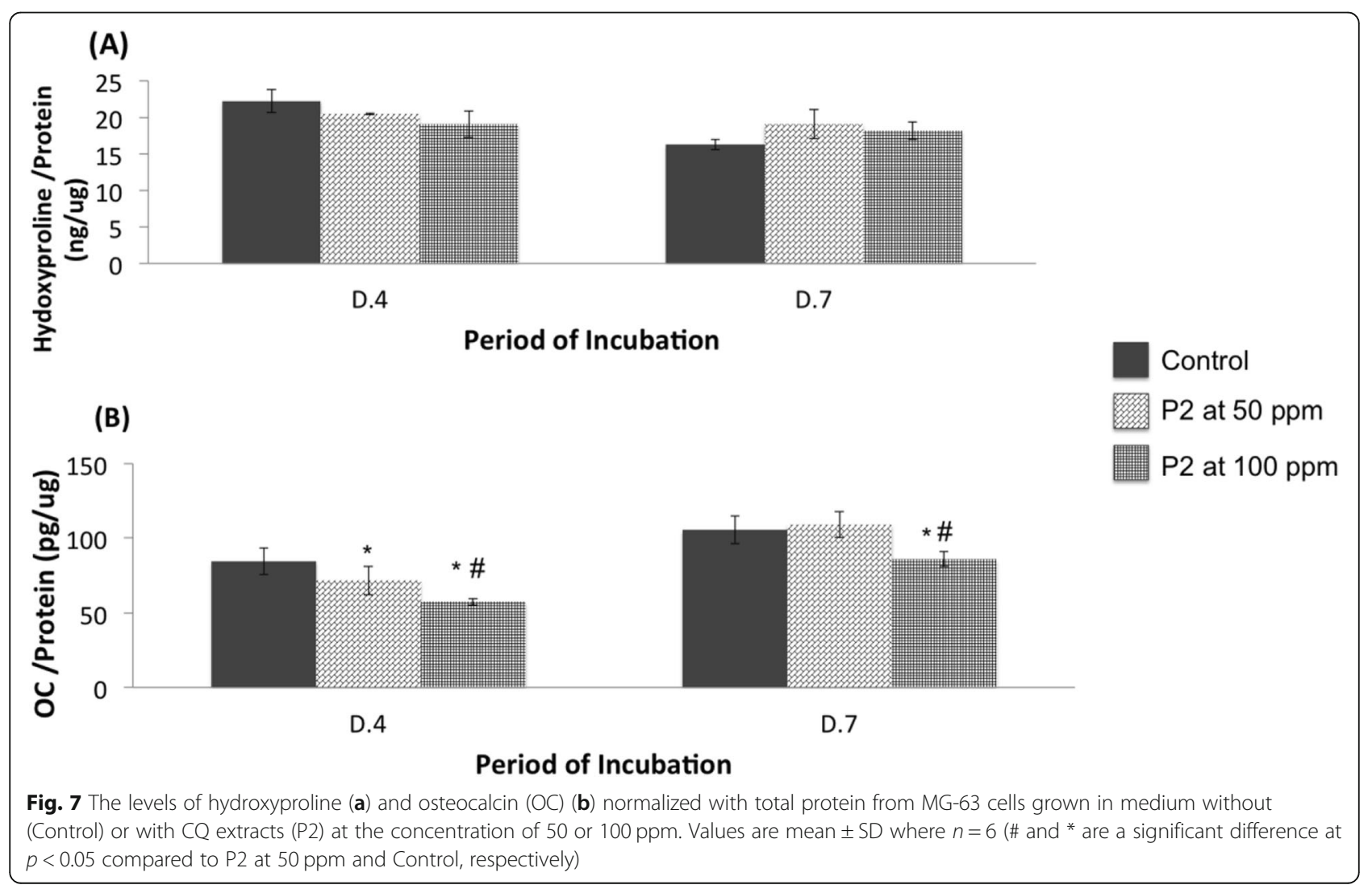


The amount of collagen production determined by levels of hydroxyproline in the cell lysates indicated that P2 slightly increased collagen production, especially on day 7 (Fig. 7a). In contrast, the levels of OC were significantly lower in P2 supplementation, (Fig. 7b).

\section{Expression of markers indicating bone resorption}

P2 had a strong effect on the expression of both OPG and RANKL in MG-63 cells. It was obvious that P2 statistically elevated the expression of OPG at both time points (Fig. 8a), and reduced the expression of RANKL production, especially at the concentration of $100 \mathrm{ppm}$ (Fig. 8b). This result led to the significant reduction of the RANKL/OPG ratio (Fig. 8c) indicating the reduction of bone resorption.
Activation of ALP activity by standard quercetin and rutin The presence of either quercetin or rutin had a positive effect on MG-63 cells by activating ALP activity (Fig. 9). The quercetin, the rutin, or a combination at a concentration equivalent to the $C Q$ extract, significantly enhanced the activity of the ALP enzyme at both time points. This result suggested that quercetin and rutin were active compounds of CQ extracts upon activation of ALP activity.

\section{Discussion}

The present study reported the consistent findings between molecular docking and in vitro experiments to highlight the effect of an ethanolic fraction (P2) of CQ after a hexane partition on an osteoblast cell line (MG63). The partition process successfully eliminated all $\beta$ -

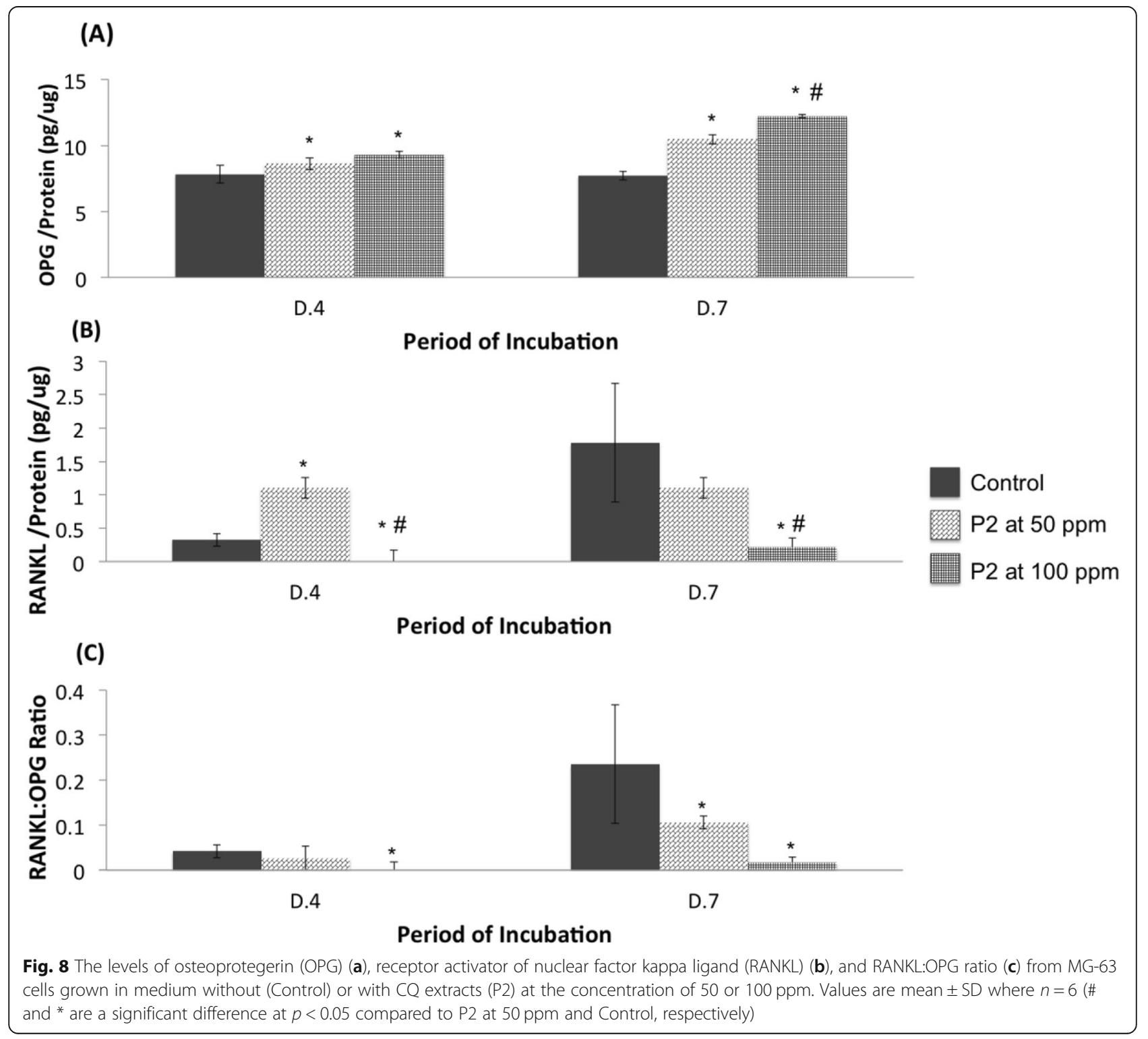




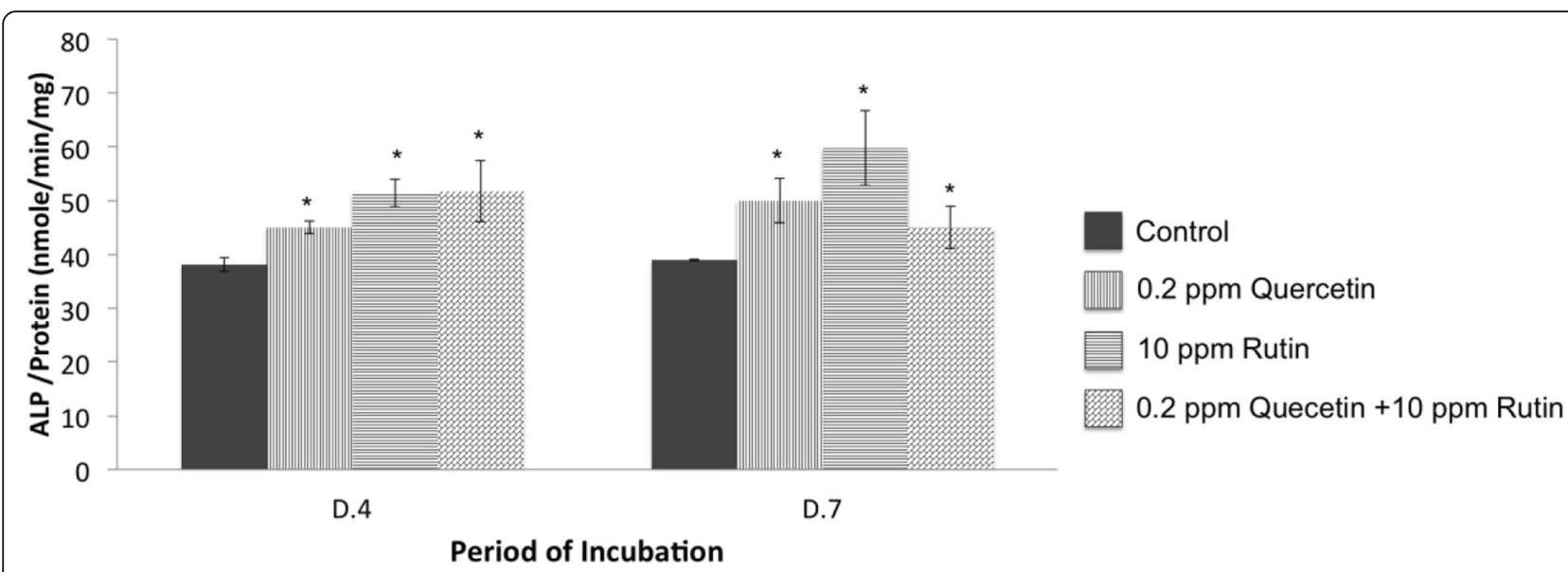

Fig. 9 The activity of alkaline phosphatase (ALP) normalized with total protein from MG-63 cells grown in medium without (Control) or with 0.2 ppm standard quercetin, 10 ppm standard rutin, or a combination of both quercetin and rutin (0.2 ppm quercetin+ 10 ppm rutin). Values are mean $\pm \mathrm{SD}$ where $n=3{ }^{*}$ is a significant difference at $p<0.05$ compared to Control)

sitosterol in the primary ethanol extract (P1). The P2 extract significantly promoted cell proliferation, ALP activity, and OPG expression, but suppressed RANKL expression. Although the hexane extract of the CQ has been reported to posses osteoblastogenesis-promoting activities observed by the activation of ALP activity [32], our results found that the removal of the hexane soluble fraction, like $\beta$-sitosterol, provided greater benefits to osteoblast cells. The evidence regarding direct effects of $\beta$-sitosterol on osteoblasts are limited. It has been documented that $\beta$-sitosterol extracted from Rubus chingii did not activate ALP activity [33]. Besides, $\beta$-sitosterol, at as low of a concentration as $16 \mu \mathrm{M}$, potentially caused cytotoxicity in breast cancer cells [34] and a leukemic cell line [35]. It is obvious in this study that both P1 and $\mathrm{P} 2$, at the maximal concentration of $100 \mathrm{ppm}$, did not cause cytotoxicity to the MG-63 cells. Our result was opposite to the recent finding that $100 \mathrm{ppm}$ ethanol extract of CQ significantly induced apoptosis, by activation of ROS (reactive oxygen species) formation and DNA fragmentation in A431, human epidermoid carcinoma cell line [36]. Moreover, the biphasic properties of the ethanolic extract of CQ were dependent on the concentration by which the extract at 75 and $100 \mathrm{ppm}$ impaired osteoblasts viability, proliferation, and minernalisation [37]. However, the in vivo model supported the use of the ethanol extracts, without partition, at a high dose of up to $500 \mathrm{mg} / \mathrm{kg}$, which caused no toxicity to the tested animals [20-23].

The presences of $\beta$-sitosterol in P1 at 50 and 100 ppm were equivalent to the $\beta$-sitosterol alone at 0.3 and $0.6 \mu \mathrm{M}$, respectively. Our study added that low concentrations of $\beta$-sitosterol had the inhibitory effect on the osteoblastic cell line used in this study. However, various concentrations of the $\beta$-sitosterol documented in publications have been reported in wide range from 0.1 to $200 \mu \mathrm{M}[38,39]$. One possible explanation why our low concentrations of the $\beta$ sitosterol in the P1 fraction of the CQ exhibited the inhibitory effects on the cells might be synergistic mechanisms with of other unknown bioactive compounds in the extract [40].

P2 fraction enhanced markers, indicating bone formation, including ALP activity and hydroxyproline levels. The presence of hexane-soluble compounds, like $\beta$ sitosterol, in P1 might have a strong effect on suppression of ALP activity, whereas the absence of the hexane-soluble compounds in P2 significantly activated ALP activity. ALP has been used as a biomarker of bone formation, in combination with other biochemical markers, detectable in serum and/or urine like terminal fragment of pro-collagen and OC [41]. Elevation of these markers indicates the process of bone formation. However, P2 fraction had no effect on the level of OC, the indicator of the bone turnover process, which includes both of the bone resorption and bone formation processes [42]. The elevation of OC indicates the high rate of bone resorption as well as bone formation [43, 44]. The enrichment with quercetin and rutin in P2 significantly reduced RANKL, but enhanced OPG levels, providing a negative effect on bone resorption processes. RANKL and OPG, mainly produced from osteoblasts, activates and inhibits osteoclastogenesis, respectively. The levels of RANKL and OPG were well regulated by various biological mechanisms to maintain bone metabolism homeostasis. The ratio between RANKL and OPG is used to compare levels of osteoclastogenesis among experimental conditions, and the increase in RANKL:OPG ratio indicate the trend to support osteoclastogensis, in vice versa $[45,46]$. 
According to the results, P2 fraction, which was enriched with rutin and quercetin, showed positive effects on bone formation. Various studies of rutin and quercetin on the support of bone formation reported that quercetin promoted osteogenesis in osteoblast cell culture model [47] and animal model [48], indicated by the increase in bone formation markers. Moreover, quercetin enhanced the osteogenic differentiation process from the progenitor stem cells [49]. In contrast, rutin had indirect support of bone formation due to the finding that it strongly increased RANKL expression in osteoblasts [50]. The effect of rutin has also been investigated in osteoclast progenitor cells, and it was found that rutin decreased ROS by deactivation of the transcription factor of NF- $\mathrm{kB}$ [51], resulting in the low level of RANK in osteoclast progenitor [52]. However, these reports used the pure compound of either rutin or quercetin at different concentrations. There is very limited evidence on osteogenic responses to the combination of both rutin and quercetin. We had also investigated the effect of the pure compound of quercetin and rutin on MG-cells. The presence of quercetin and rutin, either on its own or in combination, activated the activity of ALP, implying the support of bone formation. It is indicating that the P2 fraction of the CQ extract, rich in rutin and quercetin, had an ultimate benefit to osteoporotic patients, and the combination requires further studies.

\section{Conclusion}

The ethanolic fraction P2 of CQ extract, which is relatively enriched with both rutin and quercetin when compared to the P1 fraction, has positive effects on bone health. The markers indicating bone formation, such as ALP and collagen by hydroxyproline levels, were markedly increased when exposed to P2. In addition to the significant decrease in the markers indicating bone resorption, RANKL:OPG ratio was also observed in P2 treated cells. It could be suggested that the P2 fraction of the CQ extract might be potentially developed as a therapeutic agent for osteoporosis because of the biphasic effects (supports bone formation and inhibits bone resorption).

\footnotetext{
Abbreviations

ALP: Alkaline phosphatase; BMD: Bone mineral density; BSA: Bovine serum albumin; CQ: Cissus quadrangularis Linn; DI: De-ionized; DMEM: Dulbecco's modified eagle medium; DMSO: Dimethyl sulfoxide; ER: Estrogen receptors; FBS: Fetal bovine serum; MAPK: Mitogen-activated protein kinase; OC: Osteocalcin; OPG: Osteoprotegerin; OVX: Ovarectomised; pNP: $p$ nitrophenol; pNPP: $p$-nitrophenol phosphate; RANKL: Receptor activator of nuclear factor kappa ligand; ROS: Reactive oxygen species; RPHPLC: Reversed-phase High-performance liquid chromatography
}

\section{Acknowledgments}

The results prepared to publish in this study were one of the full research parts to develop CQ as a product for osteoporotic supplements (grant number CRP5507010920) and entirely financially supported by Agricultural Research Development Agency (Public organization), ARDA, Thailand. Laboratory facilities at Department of Biochemistry, Faculty of Medicine and
Department of Pharmaceutical Sciences, Faculty of Pharmacy, Chiang Mai University for technical support.

\section{Authors' contributions}

CS, SC and JR conceived and designed the experiments; JR., SJ, TP and CS performed the experiments; JR, SJ and CS analyzed the data; SC, JR, PS, BS, JS, and CS contributed chemicals/reagents/materials/analysis tools; JR and CS wrote the paper. The authors read and approved the final manuscript.

\section{Funding}

We wish to express our gratitude to the Agricultural Research Development Agency (Public organization, ARDA) grant number CRP5507010920 for financing.

Availability of data and materials

The supporting materials can be obtained upon request via email to the corresponding author.

Ethics approval and consent to participate

Not applicable because we did not work with animals or humans.

\section{Consent for publication}

Not applicable.

\section{Competing interests}

The authors declare that they have no competing interests.

\section{Author details}

${ }^{1}$ Department of Biochemistry, Faculty of Medicine, Chiang Mai University, Chiang Mai 50200, Thailand. ${ }^{2}$ Cluster of Excellence on Biodiversity based Economic and Society (B.BES-CMU), Chiang Mai University, Chiang Mai, Thailand. ${ }^{3}$ Department of Pharmaceutical Sciences, Faculty of Pharmacy, Chiang Mai University, Chiang Mai 50200, Thailand.

Received: 16 May 2019 Accepted: 11 March 2020

Published online: 03 April 2020

\section{References}

1. Iñiguez-Ariza NM, Clarke BL. Bone biology, signaling pathways, and therapeutic targets for osteoporosis. Maturitas. 2015;82:245-55.

2. Drake MT, Clarke BL, Lewiecki EM. The pathophysiology and treatment of osteoporosis. Clin Ther. 2015;37:1837-50.

3. Daroszewska A. Prevention and treatment of osteoporosis in women: an update. Obstet Gynaecol Reprod Med. 2015;25:181-7.

4. Makras P, Delaroudis S, Anastasilakis AD. Novel therapies for osteoporosis. Metabolism. 2015;64:1199-214.

5. Chidambara Murthy KN, Vanitha A, Swamy MM, Ravishankar GA Antioxidant and antimicrobial activity of Cissus quadrangularis L. J Med Food. 2003:6:99-105

6. Chatpalliwar VA, Verma PR, Rabra VR, Asnani AJ, Kharkar VT. Anti-nociceptive activity of Cissus quadrangularis Linn. Indian Drugs. 2004;41:290-3.

7. Jainu M, Shyamala Devi CS. Effect of Cissus quadrangularis on gastric mucosal defensive factors in experimentally induced gastric ulcer - a comparative study with sucralfate. J Med Food. 2004;7:372-6.

8. Oben J, Kuate D, Agbor G, Momo C, Talla X. The use of a Cissus quadrangularis formulation in the management of weight loss and metabolic syndrome. Lipids Health Dis. 2006. https://doi.org/10.1186/1476-511X-5-24.

9. Kumar R, Sharma AK, Saraf SA, Gupta R. CNS activity of aqueous extract of root of Cissus quadrangularis Linn. (Vitaceae). J Diet Suppl. 2010;7:1-8.

10. Panpimanmas S, Sithipongsri S, Sukdanon C, Manmee C. Experimental comparative study of the efficacy and side effects of Cissus quadrangularis $\mathrm{L}$. (Vitaceae) to daflon (Servier) and placebo in the treatment of acute hemorrhoids. J Med Assoc Thail. 2010:93:1360-7.

11. Soumya VS, Dominic S. Anti-atherosclerotic effect of ethanolic stem extract of Cissus quadrangularis Linn. Indian Drugs. 2013;50:36-45.

12. Udupa KN, Prasad GC. Cissus quadrangularis in healing of fractures. A clinical study. J Indian Med Assoc. 1962;38:590-3.

13. Rasale PL, Raut SY, Narkhede HP, Muddeshwar MG. Biochemical and hormonal evaluation of Cissus quadrangularis in accelerating healing process of bone fracture: a clinical study. Int J Res Ayurveda Pharm. 2014;5:461-9. 
14. Rao MS, Bhagath-Kumar P, Narayana-Swamy VB, Gopalan-Kutty N. Cissus quadrangularis plant extract enhances the development of cortical bone and trabeculae in the fetal femur. Pharmacologyonline. 2007;3:190-202.

15. Parisuthiman D, Singhatanadgit W, Dechatiwongse T, Koontongkaew S. Cissus quadrangularis extract enhances biomineralization through upregulation of MAPK-dependent alkaline phosphatase activity in osteoblasts. In Vitro Cell Dev Biol Anim. 2009;45:194-200.

16. Muthusami S, Senthilkumar K, Vignesh C, Ilangovan R, Stanley J, Selvamurugan N, Srinivasan N. Effects of Cissus quadrangularis on the proliferation, differentiation and matrix mineralization of human osteoblast like SaOS-2 cells. J Cell Biochem. 2011;112:1035-45.

17. Muthusami S, Ramachandran I, Krishnamoorthy S, Govindan R, Narasimhan S. Cissus quadrangularis augments IGF system components in human osteoblast like SaOS-2 cells. Growth Hormon IGF Res. 2011;21:343-8.

18. Potu BK, Bhat KMR, Rao MS, Nampurath GK, Chamallamudi MR, Nayak SR, Muttigi MS. Petroleum ether extract of Cissus quadrangularis (Linn.) enhances bone marrow mesenchymal stem cell proliferation and facilitates osteoblastogenesis. Clinics. 2009;64:993-8.

19. Pathomwichaiwat $T$, Suvitayavat $W$, Sailasuta A, Piyachaturawat $P$, Soonthornchareonnon N, Prathanturarug S. Antiosteoporotic effect of sequential extracts and freeze-dried juice of Cissus quadrangularis L. in ovariectomized mice. Asian Biomed. 2012;6:377-84.

20. Shirwaikar A, Khan S, Malini S. Antiosteoporotic effect of ethanol extract of Cissus quadrangularis Linn. On ovariectomized rat. J Ethnopharmacol. 2003; 89:245-50.

21. Potu BK, Rao MS, Nampurath GK, Chamallamudi MR, Prasad K, Nayak SR, Dharmavarapu PK, Kedage V, Bhat KMR. Evidence-based assessment of antiosteoporotic activity of petroleum-ether extract of Cissus quadrangularis Linn. On ovariectomy-induced osteoporosis. Ups J Med Sci. 2009;114:140-8.

22. Aswar UM, Mohan V, Bodhankar SL. Antiosteoporotic activity of phytoestrogen-rich fraction separated from ethanol extract of aerial parts of Cissus quadrangularis in ovariectomized rats. Indian J Pharm. 2012;44:345-50.

23. Banu J, Varela E, Bahadur AN, Soomro R, Kazi N, Fernandes G. Inhibition of bone loss by Cissus quadrangularis in mice: A preliminary report. $J$ Osteoporos. 2012. https://doi.org/10.1155/2012/101206.

24. Nathar Varsha N, Yatoo GM. Investigation on secondary metabolites in Cissus quadrangularis Linn. Int J Pharm Bio Sci. 2015;6:P349-53.

25. Nagani KV, Kevalia J, Chanda S. Pharmacognostical and phytochemical evaluation of stem of Cissus quadrangularis L. Int J Pharm Sci Res. 2011;2: 2856-62.

26. Shah U. Cissus quadrangularis L.: phytochemicals, traditional uses and pharmacological activities - a review. Int J Pharm Pharm Sci. 2011;3:41-4.

27. Mishra G, Srivastava S, Nagori BP. Pharmacological and therapeutic activity of Cissus quadrangularis: an overview. Int J PharmTech Res. 2010;2:1298-310.

28. Kamboj A, Saluja AK. Isolation of stigmasterol and $\beta$-sitosterol from petroleum ether extract of aerial parts of Ageratum conyzoides (Asteraceae). Int J Pharm Pharm Sci. 2011:3:94-6.

29. Crozier A, Jensen E, Lean MEJ, McDonald MS. Quantitative analysis of flavonoids by reversed-phase high-performance liquid chromatography. J Chromatogr A. 1997;761:315-21.

30. Adhyapak SS, Dighe W, Gokarn VN, Shambhu NA, Mestry DY. Comparison of extraction techniques for quantitative determination of rutin from Morus alba Linn. By reverse phase high performance liquid chromatography. Inr J Pharm Bio Sci. 2011;2:750-7.

31. Green GD, Reagan K. Determination of hydroxyproline by high pressure liquid chromatography. Anal Biochem. 1992;201:265-9.

32. Pathomwichaiwat $T$, Ochareon $P$, Soonthornchareonnon N, Ali Z, Khan IA, Prathanturarug S. Alkaline phosphatase activity-guided isolation of active compounds and new dammarane-type triterpenes from Cissus quadrangularis hexane extract. J Ethnopharmacol. 2015;160:52-60.

33. Liang WQ, Xu GJ, Weng D, Gao B, Zheng XF, Qian Y. Anti-osteoporotic components of Rubus chingii. Chem Nat Compd. 2015;51:47-9.

34. Awad AB, Downie AC, Fink CS. Inhibition of growth and stimulation of apoptosis by beta-sitosterol treatment of MDA-MB-231 human breast cancer cells in culture. Int J Mol Med. 2000;5:541-5

35. Park C, Moon DO, Rhu CH, Choi BT, Lee WH, Kim GY, Choi YH. B-Sitosterol induces anti-proliferation and apoptosis in human leukemic U937 cells through activation of caspase- 3 and induction of $\mathrm{Bax} / \mathrm{BCl}-2$ ratio. Biol Pharm Bull. 2007;30:1317-23.
36. Arshad M, Siddiqui S, Ali D. In vitro anti-proliferative and apoptotic effects of ethanolic extract of Cissus quadrangularis. Caryologia. 2016. https://doi.org/ 10.1080/00087114.2015.1136542.

37. Siddiqui S, Ahmad E, Gupta M, Rawat V, Shivnath N, Banerjee M, Khan MS, Arshad M. Cissus quadrangularis Linn exerts dose-dependent biphasic effects: Osteogenic and anti-proliferative, through modulating ROS, cell cycle and Runx2 gene expression in primary rat osteoblasts. Cell Prolif. 2015; 48:443-54.

38. Loizou S, Lekakis I, Chrousos GP, Moutsatsou P. $\beta$-sitosterol exhibits antiinflammatory activity in human aortic endothelial cells. Mol Nutr Food Res. 2010;54:551-8.

39. Vivancos $M$, Moreno JJ. $\beta$-Sitosterol modulates antioxidant enzyme response in RAW 264.7 macrophages. Free Radic Biol Med. 2005;39:91-7.

40. Awad AB, Burr AT, Fink CS. Effect of resveratrol and $\beta$-sitosterol in combination on reactive oxygen species and prostaglandin release by $\mathrm{PC}-3$ cells. Prostaglandins Leukot Essent Fat Acids. 2005;72:219-26.

41. Löfman O, Magnusson P, Toss G, Larsson L. Common biochemical markers of bone turnover predict future bone loss: a 5-year follow-up study. Clin Chim Acta. 2005;356:67-75.

42. Nakahama Kl. Cellular communications in bone homeostasis and repair. Cell Mol Life Sci. 2010;67:4001-9.

43. Ivaska KK, Käkönen SM, Gerdhem P, Obrant KJ, Pettersson K, Väänänen HK Urinary Osteocalcin as a marker of bone metabolism. Clin Chem. 2005;51:618-28.

44. Polak-Jonkisz D, Zwolinska D. Osteocalcin as a biochemical marker of bone turnover. Nephrology. 1998;4:339-46.

45. Boyce BF, Xing L. Biology of RANK, RANKL, and osteoprotegerin. Arthritis Res Ther. 2007. https://doi.org/10.1186/ar2165.

46. Sezer O, Heider U, Zavrski I, Kühne CA, Hofbauer LC. RANK ligand and osteoprotegerin in myeloma bone disease. Blood. 2003;101:2094-8.

47. Yang YJ, Yang ZL, Wang DC, Xiao XC, Li P. Comparative study on effects of rutin and quercetin on metabolism in osteoblast cells. J Chin Med Mat. 2006;29:467-70.

48. Tsuji M, Yamamoto H, Sato T, Mizuha Y, Kawai Y, Taketani Y, Kato S, Terao J, Inakuma T, Takeda E. Dietary quercetin inhibits bone loss without effect on the uterus in ovariectomized mice. J Bone Miner Metab. 2009;27:673-81.

49. Zhou C, Lin Y. Osteogenic differentiation of adipose-derived stem cells promoted by quercetin. Cell Prolif. 2014;47:124-32.

50. Satué M, Arriero MDM, Monjo M, Ramis JM. Quercitrin and taxifolin stimulate osteoblast differentiation in MC3T3-E1 cells and inhibit osteoclastogenesis in RAW 264.7 cells. Biochem Pharmacol. 2013;86:1476-86.

51. Kyung TW, Lee JE, Shin HH, Choi HS. Rutin inhibits osteoclast formation by decreasing reactive oxygen species and TNF-a by inhibiting activation of NF-kB. Exp Mol Med. 2008;40:52-8.

52. Rassi CM, Lieberherr M, Chaumaz G, Pointillart A, Cournot G. Modulation of osteoclastogenesis in porcine bone marrow cultures by quercetin and rutin. Cell Tissue Res. 2005;319:383-93.

\section{Publisher's Note}

Springer Nature remains neutral with regard to jurisdictional claims in published maps and institutional affiliations.

Ready to submit your research? Choose BMC and benefit from:

- fast, convenient online submission

- thorough peer review by experienced researchers in your field

- rapid publication on acceptance

- support for research data, including large and complex data types

- gold Open Access which fosters wider collaboration and increased citations

- maximum visibility for your research: over $100 \mathrm{M}$ website views per year

At $\mathrm{BMC}$, research is always in progress.

Learn more biomedcentral.com/submission 